October 1996

\title{
Voicing on the News: An Analytic Technique for Studying Media Bias
}

Stanton Wortham

University of Pennsylvania, stanton.wortham@bc.edu

Michael Locher

University of Chicago

Follow this and additional works at: https://repository.upenn.edu/gse_pubs

\section{Recommended Citation}

Wortham, S., \& Locher, M. (1996). Voicing on the News: An Analytic Technique for Studying Media Bias.

Retrieved from https://repository.upenn.edu/gse_pubs/113

Reprinted from Text: an interdisciplinary journal for the study of discourse, Volume 16, Issue 4, October 1996, pages 557-585.

Publisher URL: http://www.degruyter.com/rs/384_410_ENU_h.htm

NOTE: At the time of publication, the author was affiliated with Bates College. Currently June 2007, he is a faculty member of the Graduate School of Education at the University of Pennsylvania.

The author has asserted his right to include this material into ScholarlyCommons@Penn.

This paper is posted at ScholarlyCommons. https://repository.upenn.edu/gse_pubs/113

For more information, please contact repository@pobox.upenn.edu. 


\title{
Voicing on the News: An Analytic Technique for Studying Media Bias
}

\author{
Abstract \\ Speakers often evaluate others, implicitly, while apparently speaking in a neutral way about them. This \\ article develops an account of the textual devices speakers use to communicate such implicit messages. \\ The account draws on Bakhtin's (1981[1935]) concepts of 'voice' and 'ventriloquation.' It systematizes \\ these concepts, by proposing five specific textual devices that speakers use to convey implicit \\ evaluations. This account is then applied to samples of discourse from network news political coverage, \\ specifically coverage of the 1992 US presidential election. The five devices occur robustly in this \\ discourse. Three networks' coverage of one campaign event is analyzed in detail to illustrate how \\ newscasters orchestrate their implicit evaluations through skillful use of the five devices.

\section{Keywords} \\ indexicals, media bias, politics, quoted speech, ventriloquation, voice

\section{Comments} \\ Reprinted from Text: an interdisciplinary journal for the study of discourse, Volume 16, Issue 4, October \\ 1996, pages 557-585. \\ Publisher URL: http://www.degruyter.com/rs/384_410_ENU_h.htm \\ NOTE: At the time of publication, the author was affiliated with Bates College. Currently June 2007, he is a \\ faculty member of the Graduate School of Education at the University of Pennsylvania. \\ The author has asserted his right to include this material into ScholarlyCommons@Penn.
}




\section{Voicing on the news: An analytic technique for studying media bias}

\section{TEXT}

an interdisciplinary journal for the study of discourse

\author{
Editor \\ TEUN A.VAN DIJK
}

Offprint

\section{Mouton de Gruyter Berlin - New York}

STANTON WORTHAM and MICHAEL LOCHER

\section{Abstract}

Speakers often evaluate others, implicitly, while apparently speaking in a neutral way about them. This article develops an account of the textual devices speakers use to communicate such implicit messages. The account draws on Bakhtin's (1981. [1935]) concepts of 'voice' and 'ventriloquation'. It systematizes these concepts, by proposing five specific textual devices that speakers use to convey implicit evaluations. This accourtris then applied to samples of discourse from network news political coverage, specifically coverage of the I992 US presiddential election. The five devices occur robustly in this discourse. Three networks' coverage of one campaign event is analyzed in detail to illustrate how newscasters orchestrate their implicit evaluations through skillful use of the five devices.

Keywords: indexicals; media bias; politics; quoted speech; ventriloquation; voice.

Speech communicates more than denotational content. As Goffman $(1959,1974)$ and many others have shown, speakers inevitably adopt interactional positions with even the most mundane utterances. Knowingly or not, speakers position themselves with respect to others in the interaction, and with respect to implicit moral standards. from the culture at large. This holds for newscasters as well: Despite attempts at objectivity, newscasters adopt interactional positions and at least implicitly evaluate those they cover.

Goffman excelled at uncovering the ethically charged underside of everyday utterances. He could see and express through examples the ethical issues implicit in an interaction. This article systematizes Goffman's insights, by providing analytic tóols' for studying the interactional positioning and implicit moral evaluations he described so well. 
To do this, it borrows the concepts of voice and ventriloquation from the Russian literary theorist Mikhail Bakhtin (1981 [1935]).

In his theory of the novel, Bakhtin defines voice as an identifiable social role or position that a character enacts. Novelists portray characters as 'speaking with different voices', by describing them and putting certain words into their mouths - the words of a longshoreman, a butler, a politician, etc. Novelists also ventriloquate their characters when an 'authorial voice' enters, and takes a position with respect to a character. Ventriloquation is an author 'speaking through' a character, by aligning or distancing him or herself from that character. Bakhtin claims that, whenever an author presents the voice of another, he or she inevitably takes some evaluative position on it.

Bakhtin's theory can be applied not only to novelists, but also to any speaker who represents another's speech (Besnier, 1992; Parmentier, 1993). Newscasters, for instance, voice and ventriloquate the political candidates they cover. Like novelists, newscasters portray their subjects as being particular kinds of people. Newscasters also implicitly evaluate these subjects. Through systematic analyses of voicing and ventriloquation in newscasts, this article shows how Bakhtin's theory-suitably systematized-can illuminate media bias.

The first section below sketches Bakhtin's theory of novelistic discourse, and briefly reviews some contemporary work on media bias. The second section presents a more systematic account of how speakers accomplish voicing and ventriloquation. The third section uses these systematic techniques to analyze implicit messages in network news coverage of the 1992 US presidential campaign.

\section{Voicing and ventriloquation}

Bakhtin's work on novelistic discourse is sufficiently complex that we cannot claim to offer a univocal interpretation. Given Bakhtin's love of polyphony, such a claim would be both unwise and ironic. We claim only that our account clarifies the phenomenon of media bias, and that it identifies common textual devices that make voicing and ventriloquation possible. According to Bakhtin's theory of language use, every word comes with certain social locations attached.

All words have the 'taste' of a profession, a genre, a tendency, a party, a particular work, a particular person, a generation, an age group, the day and hour. Each word tastes of the context and contexts in which it has lived its socially charged life. (Bakhtin, 1981 [1935]: 293)
To use language inevitably indexes the social locations that go with the words used.

Language does refer to the world, and it does express the speaker's thoughts and feelings, but in doing so it also locates the speaker and what he or she is talking about at some spot in the social world. The speaker claims to be the kind of person who uses these words, and the hearer is the kind of person who is spoken to this way. Only certain types of people would use 'collateral damage' to refer to civilian casualties of war: military personnel, someone trying to sound like an expert, or someone politically in favor of the war (but not a peace activist).

Bakhtin calls the words and constructions that go with each location a 'speech genre'.

Each sphere in which language is used develops its own relatively stable types of ... utterances. These we may call speech genres. The wealth and diversity of speech genres are boundless because the various possibilities of human activity are inexhaustible. (Bakhtin, 1986 [1953]: 60).

All speech 'tastes' of one or more speech genres. Or, in another Bakhtinian metaphor, every use of language reverberates with the 'echoes' of a role, a type of person, an institutional setting or event.

Bakhtin calls the process of working out speakers' social locations 'voicing'. To speak with a 'voice' is to use words that identify oneself as being from a recognizable social location. 'Voicing' is the process of blending several voices together into a coherent interaction. Bakhtin's metaphor for this process is musical: voices are 'orchestrated' into a coherent whole. In conversation, this requires coordination among speakers. In the novel-which is Bakhtin's main focus-the artist represents events so as to orchestrate several voices into a coherent whole. What makes a novel coherent is not just plot structures or themes, but the way the novelist represents recognizable voices and places them in imagined interactions. By representing characters and events, novelists bring to life a recognizable social world, with particular voices juxtaposed.

This representation and juxtaposition of voices is not objective. An authorial voice always moves among and evaluates the various voices in a novel. Readers often hear the author's voice in how the novelist represents characters' speech, In such a case, the author 'speaks, as it were, through language, a language that has somehow more or less materialized, become objectivized, that he merely ventriloquates' (Bakhtin, 1981 [1935]: 299). The authorial voice implicitly comments on the social world it represents. Largely through linguistic devices for representing speech, the novelist positions him or herself with respect, to the voices of the characters. The author communicates his or her own social and ethical 
positions by 'ventriloquating' the characters--by using their speech to express his or her own position.

When Dickens, for instance, parodies self-satisfied businessmen, he is evoking a recognizable social role and evaluating it. Dickens lampoons his petty bourgeois characters. He achieves this by contrasting their conceptions of themselves with an authorial commentary on their true social character. Bakhtin gives an example from Dickens' Little Dorrit:

It was a dinner to provoke an appetite, though he had not had one. The rarest dishes, sumptuously cooked and sumptuously served; the choicest fruits, the most exquisite wines; marvels of workmanship in gold and silver, china and glass; innumerable things delicious to the senses of taste, smell, and sight were insinuated into its composition. $O$, what a wonderful man this Merdle, what a great man, what a master man, how blessedly and enviably endowed-in one word, what a rich man! (Little Dorrit, book 2, chapter 12; quoted in Bakhtin, 1981 [1935]: 304, Bakhtin's emphasis)

As presented here and earlier in the novel, the character Merdle speaks with a definite voice: a rich businessman who is admired by others, and admires himself, because of his wealth. In this passage Dickens parodies Merdle and his fawning admirers, and exposes their hypocrisy. In the italicized sentence, the admirers praise Merdle for his exemplary qualities. But Dickens" voice enters at the end-and claims that, despite their fancy praises, they admire Merdle only for his money.

So novelists do not just represent social worlds: The novelist juxtaposes certain voices so as to convey an evaluation of them. "The prose writer makes use of words that are already populated with the social intentions of others and compels them to serve his own new intentions, to serve a second master' (Bakhtin, 1981 [1935]; 299-300). A novel's theme, then, is not merely a denotational message. Any significant novel goes beyond the lives of its characters to assess some aspect of the social world in general. Thus the social world (as pointed to by language) is both the mechanism through which the novelist works and the object about which he or she intends to speak.

Any speaker talking about others occupies a position partly analogous to a novelist's. Like novelists, speakers present others as if they speak with certain voices. Especially when they represent others' speech, speakers cast others in specific social positions. Speakers also ventriloquate those they talk about. By giving them particular voices and placing them in types of social events, speakers evaluate those they describe. (Besnier [1992] and Parmentier [1993] make this same point, and illustrate it with examples from other societies and other institutional settings.)

Like other speakers, newscasters portray their subjects as people who speak with identifiable voices. And they themselves speak through these voices and evaluate those they cover. Previous work on media discourse and media bias has established that "news is determined by values, and the kind of language in which that news is told reflects and expresses those values' (Bell, 1991: 2). Bell describes how news texts are multilayered products, and thus makes clear that most implicit values expressed in newscasts are complex and not fully intentional. Nonetheless, as Davis and Walton (1983) and others have shown, newscasts do often express coherent evaluative positions.

Having established that newscasts are biased, and that analysts can uncover these biases by examining media discourse, two tasks remain. First, as van Dijk (1988) argues, we need a more comprehensive theory of the social context and social functions of media discourse. Second, we need a more rigorous account of the discursive mechanisms newscasters use to communicate implicate biases (Verschueren, 1985). Work that speaks to both these issues has begun to emerge (Fairclough, 1995; van Dijk, 1988). In this article we offer an analytic tool to enrich such emerging frameworks, in the form of a linguistically rigorous technique for uncovering concrete instances of media bias.

\section{Textual resources for voicing and ventriloquation}

Describing a verbal interaction relates two events of language use, the narrating and the narrated (Jakobson, 1971 [1957]). Many contemporary analyses of language use have shown the utility of this distinction (e.g., Schiffrin, 1990; Silverstein, 1976; Verschueren, 1985). A news broadcast is a narrating event. The anchor and correspondents speak among themselves and both speak to the audience. The events discussed, like political candidates' statements, are narrated events. Bakhtin's claims, put into this terminology; are that a speaker's descriptions of a narrated event inevitably (1) attribute social positions to those described and (2) express, in the narrating event, the speaker's own social position and attitude with respect to those described.

This section presents a systematic technique for identifying such attributions and evaluations in discourse. First, the analyst identifies all tokens of certain textual devices that speakers commonly use to voice and to evaluate their subjects. Silverstein $(1988,1993)$ has suggested five types of textual devices used in voicing and ventriloquation:

1. Reference and predication

2. Metapragmatic description

3. Quotation 
4. Evaluative indexicals

5. Epistemic modalization

The following paragraphs describe these devices, and give brief examples. The next section illustrates in detail how newscasters use these devices to convey implicit messages about political candidates.

I. Reference and predication. Reference is the picking out of things in the world by linguistic means. Predication characterizes the objects picked out. People may be strongly or weakly characterized through the grammatical machinery that contributes to reference. Such characterizations socially identify the referents: people are referred to and predicated of such that they fit identifiable social types.

Reference to characters in a narrated world may involve the use of proper names, with or without titles, kin terms, or any of a number of other possibilities according to cultural rules, all of which function to characterize the referent in some way. Consider these examples:

(1) a. Tom promised to take me to a movie this week; now the bastard [i.e., Tom] is trying to get out of it.

b. That klutz Bob spilled coffee on me again today.

In both cases there is a strongly negative evaluation of the person referred to by the narrator, and those negative evaluations are communicated primarily through the terms used to refer to Tom and Bob.

A narrator referring to a character as 'Mr. Johnson' or 'my cousin' puts him or herself in a particular social relationship to that character, and is thereby located in a particular social universe with respect to the character. Some forms of reference strongly entail certain frameworks of relationship ('my cousin'), while others do this less ('the man').

The use of adjectives and predicational machinery by the narrator also functions to place characters, evaluatively, in a narrative. Thus a noun that has little evaluative power by itself ('the man') may be made highly evaluative by adding an adjectival string:

(2) a. The surly man dressed in filthy rags ...

b. The kind-faced man in the top hat ...

With such use of language the narrator places the characters in particular social and economic groups (stereotypically defined), and takes an evaluative stance with respect to them - that is, the novelist voices and ventriloquates them.

II. Metapragmatic descriptors. These centrally include the so-called verba dicendi, or verbs of saying, which describe instances of language use (and are thus 'metapragmatic': language used to refer to and predicate about language in use $-\mathrm{cf}$. Silverstein [1976] and Verschueren [1985] on the power of metapragmatic discourse to carry social messages). Characterizing someone's speech using metapragmatic verbs is a powerful means of voicing and ventriloquation. Consider these alternatives:

(3) a. Tom spoke

b. Tom lied.

c. Tom hemmed and hawed.

d. Tom whined.

e. Tom rhapsodized.

Each of these examples represents an instance of speaking in a particular way, with the narrator limiting the type of social role that the character Tom might be playing. In using one verb and not the others, the narrator can also provide a moral evaluation of Tom.

In English, the verb to say is the most value-neutral of the metapragmatic verbs: in most contexts, no perspective can be discerned based on its usage alone (cf. Goossens, 1982). On the other hand, a verb like to filibuster describes an instance of speaking in such a way that the speaker in the narrated event (someone officious, if notractually an official) and the speech (a barrage of verbiage intended to keep others from taking the floor in an interactional event) are projected into a distinctive social role.

A related grammatical feature of languages is the nominal metapragmatic characterization of events (speeches, lies, poems, promises, etc.). These denote particular types of speech, and by characterizing the style and/or content of the speech, thereby project both narrators and speakers into social roles. A 'keynote address' is a particular kind of speech normatively delivered on particular kinds of occasions - and not in the middle of a golf course, for instance.

III. Quotation Quotation is a combination of reference, metapragmatic verb, and utterance to represent some instance of speaking. Quotation can range from near-absolute mimicry through quasi-direct discourse to indirect quotation (Clark and Gerrig, 1990; Mayes, 1990; Vološinov, 1986 [ 1929]). The first possibility is a conventional attempt to re-present exactly the utterance of the speaker, while the various degrees of indirection involve translation: Consider this example, with quotations arranged from more to less direct:

(4) a. Tom (on the phone to the narrator): I'll be there in an hour.

b. Narrator: Tom said, 'I'll be there in an hour'.

c. Narrator: Tom said, he'll be here in an hour.

d. Narrator: Tom said that he's coming soon. 
(In this example bold terms are those that remain constant from the initial statement to the translation, underlined terms are the metapragmatic verbs and related grammatical machinery that characterize the act of speaking, and italicized terms are those that change from the original statement to the translation with respect to the deictic origo of the narrator). There are a number of effects that go with the various forms of quotation, particularly with respect to the deictics embedded in the quotation, with a tendency to relativize those deictics as quotation gets more indirect (Mayes, 1990).

Even in direct quotation, however, the narrator inevitably filters the quoted speaker's message - if only by selection of the quote, choice of framing material, and intonation (Clark and Gerrig, 1990; Waugh, 1995). Indirect quotation provides even more opportunities for the narrator to provide his or her own implicit take on the quoted speaker. When a novelist puts words in a character's mouth, then, he or she has the opportunity to use words that identify the character as a particular sort of person-as a person who speaks with a certain voice. By choosing the quoted speech carefully, the novelist can also ventriloquate the character's words and convey his or her own implicit evaluation of the character.

IV. Evaluative indexicals. These are often tokens of particular registers (ways of speaking associated with a particular social group). According to the folk-sociolinguistics of every speech community, there are certain utterances (emblems, Silverstein [1988] calls them) that are stereotypically associated with certain types of people. These emblems may be lexical items, grammatical constructions, accents, or any of a number of other forms.

Use of evaluative indexicals (tokens of particular registers) indexes speakers as being of the social groups that characteristically use them. Speakers may index their occupations, regional origins, genders, etc., in their choice of emblems. Narrators may project their characters into particular social toles by putting particular emblems into their mouths. Consider the following passage from a short story by Thomas Pynchon:

Presumably intelligent talk flickered around the room with the false brightness of heat lightning: in the space of a minute Siegel caught the words 'Zen', 'San Francisco', and 'Wittgenstein', and felt a mild sense of disappointment, almost as if he had expected some esoteric language, something out of Albertus Magnus. (Pynchon 1959: 205)

With three simple terms Pynchon characterizes (voices) an entire roomful of people.
This passage also illustrates ventriloquation. The three emblems are used in two ways: they are utterances spoken by people in the room and overheard by Siegel, and they. are also held up by Siegel as objects, the meanings of which are primarily as indexes of particular social types. The narrator's sarcastic characterization of the talk as 'presumably intelligent' expresses his evaluation of the voice represented.

V. Epistemic modalization. Epistemic modalization is the comparison of the epistemological status of the narrating and narrated events. Narrators can claim to have a God's-eye view, or to be merely participating in a contingent event of speaking in the same way as the narrated characters. With respect to the narrated event, narrators can ascribe greater epistemic access to certain characters, and less to others. The 'calibration' of epistemic status across narrating and narrated events (see Silverstein, 1993) can, for instance, be accomplished through formulae that place the narrated event out of space and time-as in 'once upon a time .... This work can also be done grammatically, through verb tenses.

Epistemic modalization contributes to both voicing and ventriloquation. During the 1992 US presidential campaign, for example, CBS news ran a regular segment called 'Reality Check'-in which reporters assessed the truth of candidates' claims. On many occasions the reporters would claim that candidates had insufficient information to substantiate their accusations about each other. Thus they voiced the candidates, characterizing them as politicians who 'spin' limited information into grand, selfserving claims. And the reporters presented themselves as reasonable people who had looked up the relevant information and were now presenting all the facts. By giving themselves this privileged epistemological position, the reporters were able to ventriloquate the candidates: implicitly, the reporters aligned themselves with the public and shook their heads in disgust at the lying politicians. See Locher and Wortham (1994) for more on the trope of "objectivity" in the news.

We must stress that these five devices do not provide a mechanical method for identifying voicing and ventriloquation. We do claim that tokens of these devices will provide much (though not all) of the structure through which speakers identify and evaluate their subjects' social positions. So examination of these five devices in a text will provide many important clues. But an analyst cannot simply compute the voicing and ventriloquation after identifying these five devices. Instead, tokens of the devices provide clues, from which the analyst must infer an interpretation of the voicing and ventriloquation. As in any herneneutic process, all such interpretations are open to challenge and revision. Put simply, this 
interpretive process involves asking three questions: given the tokens of the five devices ised by the speaker, what voices are being attributed to the characters? Given these tokens, what type of interactional event is the speaker establishing for the narrating event? (In the CBS newscast analyzed below, for instance, the narrating event is a mock trial.) What role is the speaker playing in this narrating event, and what is his or her position with respect to the various characters?

\section{Voicing and ventriloquation on the news}

This section first reports the incidence of the five textual devices in a sample of newscast discourse. Then it provides detailed examples of voicing and ventriloquation on the news, to show how newscasters deploy the devices in context. We summarize the incidence of the five textual devices here in order to establish that the resources for voicing occur robustly in newscast discourse. We must emphasize that the occurrence of one device token does not in itself constitute voicing. Like other speech events, voicing is a textual phenomenon. In almost all cases successful voicing depends on a pattern of textual cues and contextual presuppositions, not simply on the occurrence of one indicating device (cf. Levinson [1981] and Silverstein [1992] on the distinction between indicator and textual accounts of language use). So the statistics below do not summarize how often voicing occurs in newscasts. Instead, they summarize how often the devices used to establish voicing occur. In most cases speakers will use many device tokens to establish the voicing and ventriloquation of one set of characters.

The context-dependence of voicing raises problems, in particular, when one tries to count instances of the five devices. Not every linguistic form that refers to or predicates of an individual, not every metapragmatic descriptor, and not every quotation will contribute to voicing or ventriloquating someone. Every such device has the potential to do so-and quotations in particular generally do-but in practice not every instance will contribute. As texts can be interpreted in multiple ways by speakers and analysts, however, it is sometimes difficult to tell whether a certain device token is contributing or not. For this reason, we have counted every instance of reference to or predication about human individuals or groups, every metapragmatic descriptor, and every quotation in our data.

Evaluative indexicals and epistemic modalization presents further problems. Fluent speakers unfamiliar with the context would generally agree on what forms establish reference and predication, metapragmatic description, and quotation. But context plays more of a role in establish- ing that a particular form counts as an evaluative indexical or an epistemic modalizer. One must know something about John Sununu to know that implicitly comparing someone with him might well index the character as a certain, evaluatively loaded kind of person. One must also know something about what people consider epistemologically justified in order to identify some instances of epistemic modalization. Some US journalists might well voice and ventriloquate Alberto Fujimori's consultations with shamans differently than the indigenous Peruvian press. Given our general knowledge as US citizens who followed the 1992 presidential campaign fairly closely, we have done our best to identify instances of evaluative indexicals and epistemic modalization in the data. As with the first three devices discussed above, note that we have counted every linguistic form that might contribute to voicing and ventriloquation, even though speakers generally use several forms to establish only one set of voices.

The sample of newscast data comes from a larger study of network news coverage from the 1992 US presidential campaign (Locher and Wortham, 1994). We recorded virtually every network news broadcast between Labor Day and Election Day, on ABC, CBS, PBS, and the CNN Spanish language broadcast (called CND/Telemundo at the time) We have coded about one-third of these broadcasts, for the occurrence of metapragmatic descriptors, quotation, and evaluative indexicals. For this article, we randomly selected a 6000 word transcribed corpus and counted every occurrence of the five types of devices. Table 1 contains the results.

So these five resources for voicing and ventriloquation occur commonly in news coverage of politics. The following analyses show how-newscasters use the five devices to establish particular voicing and ventriloquation, and thus illustrate how attention to these devices can be useful in uncovering media bias. (For reasons of space, and also because the verbal patterns in these newscasts are quite robust, the analyses below focus only on the newscasters' utterances and not on the visuals. We believe that in these cases the visuals largely complement the patterns described in our analyses, but a complete analysis would require attention to all the semiotic

Table 1. Incidence of textual devices used for voicing (per 100 words)

\begin{tabular}{cc}
\hline \multicolumn{1}{c}{ Device } & Nowscast sample \\
\hline I. Reference and predication & 11 \\
II. Metapragmatic descriptors & 4 \\
III. Quotation . & 2 \\
IV. Evaluative indexicals & 2 \\
V. Epistemic modalization & 3 \\
\hline
\end{tabular}


cues in the text.) On October 30,1992-four days before the US Presidential election-a a special prosecutor released notes written in 1986 by Caspar Weinberger (Ronald Reagan's Secretary of Defense). The notes were released as part of a grand jury indictment that alleged Weinberger had lied to Congress, while attempting to hide the fact that Reagan knew beforehand and approved of the 1986 shipment of missiles to Iran. The notes were a lead story for television news that evening, because they contradicted Bush's repeated statements that he did not know of the arms sale ahead of time.

This section analyzes three national newscasts from that eveningCNN/Telemundo (a Spanish language broadcast produced in the United States), ABC World News Tonight and CBS Evening News. CNN and $A B C$ cover the release of the notes in similar ways, with some differences in ventriloquation, Both networks present Bush as morally suspect. CNN seems to take his alleged lies more seriously, however, while ABC presents them as just part of the political game. CBS takes the allegations most seriously of all. Their report on the Weinberger notes becomes a mock trial of Bush-with Bush voiced as a criminal defendant.

First we need an overview of how the networks organized their coverage. The following list gives the topics discussed, in order, during both CNN and ABC coverage of the Weinberger notes:

1. Introductory sentence/frame

2. Summary of Bush's past claims about his knowledge

3. Introduction of Weinberger note, apparently contradicting Bush

4. Description of specifics of note itself

5a. CNN: summary of implications of note

5b. ABC: description of release of note

6. Description of conclusions Clinton campaign draws from note

7. Description of conclusions Bush campaign draws from note.

On CNN there are two anchors (Patricia Janiot and Jorge Gestoso). Janiot introduces the issue of Weinberger's notes at the beginning of the newscast, as part of a frame for CNN's campaign coverage that day:

[Al mismo tiempo] que el Presidente Bush recibla la buena noticia de que prácticamente ha alcanzado a su rival Bill Clinton en nuestra encuesta de CNN, al mismo tiempo se enteraba de dos escándalos que a solo cuatro dias de las elecciones lo pueden perjudicar mucho pollticamente. Comenzemos por las encuestas ...

[Just as] President Bush received the good news that he has almost overtaken his rival Bill Clinton in our CNN poll, he learned of various scandals that, coming oniy four days from the elections, might cause him substantial political damage, We begin with the polls...
After Janiot discusses the latest CNN poll (which has Bush now only one percent behind among likely voters - the closest he has ever been, and the closest he ever gets, during this campaign), Gestoso discusses the first of the 'scandals'. This is the Weinberger notes and the Iran arms shipment. The second scandal involves comuption charges against the US treasurer, who was at the time the highest ranking Hispanic official in the government. CNN discusses this second scandal even more extensively than the Weinberger notes, because of its particular interest to their audience. $\mathrm{ABC}$ and CBS do not mention the charges against the treasurer at all.

Gestoso introduces the Weinberger story by indexing the 'good news, bad news' frame that Janiot established. (The bracketed numbers in the transcripts below correspond to the list of topics given above).

[1] Y Patricia la primera de las malas noticias para Bush, está relacionada con el escándalo Iran-Coitras. [2] Desde que se descubrio el escándalo Bush dijo haber estado completamente al margen del intercamblo de armas por rehenes. [3] Pero hoy fue dada a conocer una segunda acusación formal contra el ex-Secretario de Defensa, Caspar Weinberger, que estarla contradiciendo los dicho por Bush

[1] And Patricia the first piece of bad news for Bush is connected to the IranContra scandal. [2] Since the scandal became known Bush has said that he was completely marginal to the exchange of weapons for hostages. [3] But today a second formal charge was made public against ex-Secretary of Defense Caspar Weinberger, which would contradict Bush's statements.

Note first the word escandalo. While referring to the event in question (device \#1), this word also suggests that the arms shipment was both politically dangerous and morally questionable. 'The Iran-Contra scandal' was a phrase in wide use, but neither ABC nor CBS uses 'scandal' in their coverage of October 30-so its implications may well be connected to the particular voice CNN attributes to Bush. The term 'scandal' starts to suggest a voice for Bush, as a morally suspect politician who has gotten himself in trouble. Note also the metapragmatic verb contradiciendo in this passage (device \#2): This is a blunt statement by Gestoso, that the new evidence contradicts what Bush has said. (And Weinberger is said to contradict Bush, not the other way around.) We will see that $\mathrm{ABC}$ does not put the point so bluntly. On CNN, as Bush is being contradicted by the facts, we have more grounds to suspect his morals.

The force of this charge against Bush increases as Gestoso goes on to document, in detail, the facts established by Weinberger's notes.

[4] La acusación èstá basada en las notas inscritas de Weinherger sobre una retutión que mantuvo en enero de 1986 en la Oficina Oval, a la cual asistis el entonces Vice Presidente Bush. Segion las notas, en la retnión se trató el tntercambio de armas 
por rehenes, y especificamente esta oferta, cinco rehenes Estadountdenses por 4000 misiles TOW para Iran. la nota de Weinberger dice textualmente, George Schultz, y. yo en contra, Bull Casey, Ed Meese y el Vice Presidente a favor. [5] El Presidente Bush ha dicho que él no supo hasta mediados de diclembre del.1986 del intercambio de armas por rehenes. Esta reinion pondria a Bush en el medio de la discusión de esa declsión cast in afio antes.

[4] The charge is based on notes written by Weinberger about a meeting he had. in January, 1986 in the Oval Office at which then Vice President Bush was present: According to the notes in the meeting they discussed the exchange of weapons for hostages, and specifically this offer: five American hostages for 4000 TOW missiles for Iran, Weinberger's note says literally; George Schultz and I opposed, Bill Casey, Ed Meese and the Vice President in favor. [5] President Bush has said that he did not know about the exchange of arms for hostages until the middle of December, 1986. This meeting would put Bush in the middle of the discussion of that decision almost one year before that.

Note here Gestoso's concern with the epistemic status of the Weinberger notes (device \#5). He describes, "specifically"; the exact offer that was discussed and recorded in the notes. The inclusion of specific numbers here makes the facts of the offer and the discussion seem more certain. He also claims to describe what the notes say, 'literally'. The evidence that contradicts Bush-and thus suggests he is morally suspect-comes, word for word, from something objective.

We also begin to see Gestoso's ventriloquation of. Bush here. Note the use of Bush's quoted speech to set up the contradiction between his claims and the evidence testified to by the note. Above, under [2], Gestoso has Bush claim to have been 'at the margin' of the exchange (device \#3). But in [5], after another Bush quote in which Gestoso has him directly contradicting the evidence, Gestoso describes Bush as 'in the middle' of the proposed exchange. So, in his summary of the implications that this new evidence has for Bush, Gestoso seems to emphasize the contradiction between Bush's claims and the evidence. He presents the evidence strongly - emphasizing its objectivity and not mentioning its possible political motivation (unlike ABC, as we will see below). And he puts Bush right in the middle of the scandal, in the face of Bush's claims to be marginal.

The CNN coverage concludes with summaries of Clinton and Bush reactions to the Weinberger notes.

[6] Bill Clinton reacionó ante la noticia diciendo que esta acusación formal, es la prueba concreta de que Bush le ha estado mintlendo al pueblo estadounidense, y el questionamiento que Bush ha venido haciendo de la integridad moral de Clinton funabnente ha tenido un efecto de boomerang para el Presidente. [7] Por su parte. Bush, a través de sus asistentes de campanta, dijo que todo esto es, basura politica.
[6] Bill Clinton reacted to the news by saying that this formal charge is definitive proof that Bush has been lying to the American people, and that the questions that Bush has been asking about Clinton's moral integrity have finally had a boomerang effect against the President. [7] For his part, Bush, through his campaign spokesmen, said that all of this is political garbage.

Note here what we have called (Locher and Wortham, 1994) an 'embedded metapragmatic' construction: 'Clinton reacion $\delta$.... diciendo que esta ... es la prueba ... de que Bush le ha estado mintiendo'. There are two levels of metapragmatic verbs here, and three events of speaking, embedded one within the other. Gestoso is reporting that Clinton said that Bush has been lying. Questions of voicing and ventriloquation are, of course, questions about thie 'outermost' event of speaking (the narrating event, in Jakobson's terms)-that between Gestoso and the audience: what sort of person is Gestoso presenting Bush as, and what is Gestoso's attitude toward Bush? In an embedded metapragmatic construction, the speaker (Gestoso) augments his resources for voicing and ventriloquation. Not only does he havie the opportunity to select a metapragmatic verb and to put words into the first embedded speaker's mouth (Clinton, in this case), but he also has a chance metapragmatically to characterize the second embedded speaker (Bush). In this casers in many other embedded metapragmatic constructions we have identified, the more highly charged verb is put in the mouth of the first embedded speaker. Note that if Gestoso had said 'Bush is lying', he himself would be responsible for this choice of verb. But by saying 'Clinton said Bush is lying', Gestoso can claim that he himself never accused Bush of lying. He was just reporting what Clinton said (cf. Irvine [1992] for discussion of another type of speech event where speakers can distance themselves from responsibility for uttering interactionally potent messages). Nonetheless, despite the deniability, Gestoso gives us the message that Bush was indeed lying. This further supports the reading given above - that Gestoso is himself taking very seriously the possibility that Bush has been lying. But we should not place too much weight on the evidence from this particular embedded metapragmatic construction alone, because $A B C$ uses almost exactly the same one in the service of somewhat different ventriloquation.

$A B C$ 's coverage of the Weinberger notes, while longer than CNN's (about 550 words, to CNN's 300), is remarkably similar in structure. With the exception of topic [5] in the list above, ABC covers the same topics in the same order as CNN. ABC's voicing and ventriloquation of Bush is in some ways similar to CNN, and in some ways different. The $\mathrm{ABC}$ anchor, Peter Jennings, starts the October 30 newscast as follows:

[1] The question of truth and character came up again today, for President Bush. [2] The president has always denied knowing that the Reagan Bush administration 
was trading anms for hostages with the Iranians in 1986. I was, he's always said, out of the loop. [3] Today a note written by then-Secretary of Defense Caspar Weinberger puts Mr. Bush at an Oval Office meeting where a specific deal, missiles for hostages, was discussed and approved.

While for CNN the initial topic was the 'bad news' of 'scandals', here it is the 'character' issue. Because Jennings frames character as a 'question', we suspect that the topic is someone's questionable character, or at least someone's morally questionable actions. Note the slight hesitation, before Jennings tells us whose character is being questioned. He may be introducing a bit of drama here. Throughout the campaign, Bush constantly questioned Clinton's character. And here, by beginning his utterance with questions of character, Jennings sets up the audience to expect another Bush attack on Clinton. But we discover at the end of the utterance that it's Bush's character at issue this time. We will see further evidence below that the overall frame here is one of reversal: Bush has been questioning Clinton's character, and in Weinberger's notes we have news that allows Clinton to return the favor. Jennings' attitude - if wo can anticipate our reading of his ventriloquation - might be summed up in the aphorism. 'turnabout is fair play'. By focusing on the reversal, ABC makes the. accusation against Bush seem part of the political game. This contrasts somewhat with CNN, and clearly with CBS, which take Bush's 'bad news' more seriously:

Under [2], Jennings presents Bush's prior claims in a way similar to CNN. Bush 'denied' prior knowledge of the arms deal (device \#2). Note that the verb deny often indexes the subject as potentially immoral. Politicians and criminals are forever denying things that everyone knows are true. But this is so far only suggestive. As with CNN, things get more serious for Bush as Jennings details the evidence from Weinberger's notes. He describes a 'specific' deal (device \#5), which Bush and others 'discussed' and 'approved' (device \#2). Note, however, that Jennings, unlike Gestoso, leaves the 'contradiction' between Bush's claims and Weinberger's notes implicit. As elsewhere, Gestoso's account here presents Bush with a more serious moral problem than Jennings's.

Nonetheless, like Gestoso, Jennings does present the evidence that contradicts Bush, and he also takes pains to establish the epistemological. status of the notes.

[4] The note says, [text on screen, with picture of Weinberger] President decided to go with Israeli-Itanian officer, offer to release our five hostages, in return for the sale of 4000 . TOW, those are anti-tank missiles, to Iran by Igrael. Mr. Weinberger's note goes on, George Schultz, the Secretary of State and I opposed, Bill Casey, the ClA director, Ed Meese, the Attorney General, and VP, Yice President Bush, favored. The note was released by the special prosecutor, who was sceking a new indictment of Mr. Weinberger, for lying to Congress about the Iran-Contra affair.

By having the text reproduced on screen, and by mentioning the specific numbers in the proposed exchange, Jennings makes the evidence seem robust (device \#5). He also slips in the metapragnatic yerb 'lying' (device \#2), referring to the prosecutor's charge against Weinberger. In doing so he associates Bush with an accused liar.

Note, however, the difference from CNN in topic [5]. While Gestoso summarized the contradiction between Bush's claims and the evidence, Jennings mentions the source of the Weinberger notes: the special prosecutor. By giving us a human agent responsible for the release of the notes, Jennings at least implicitly raises the possibility that the notes might be appearing now in order to embarrass Bush. CNN, in contrast, describes the appearance of the notes in entirely impersonal terms - 'se enteraba diversos escándalos' (he learned of various scandals); 'fue dada a conocer' (it became known) - as if no political agent had a hand in producing them at this moment in the campaign. Together with the absence of the explicit reference to 'contradiction', this difference softens Jennings' portrayal of Bush's predicament a bit. Bush is still voiced as a patential liar, but Jennings seems not to take the potentialtransgression as seriously as Gestoso.

ABC's description of Clinton's response puts the accusation against Bush more strongly, as we might expect.

[6] JENNINGS: Governor Clinton's campaign said today, this was the smoking gun which shows the President has been lying. Here's ABC's Chris Bury.

BURY: This afternoon the Governor used the Iran Contra revelations to attack the President on the very issues Bush has raised so often against him.

CLINTON: President Bush says this election is about trust and character and judgment. He has seriously, called into question, those issues and now has to answer your questions on all three counts.

BURY: Clinton said questions about his behavior as a student, cannot be compared with questions about Bush's behavior as Vice President.

CLINTON: He has, vigorously attacked me for, going to the Soviet Union as a student, or uh- my actions with regard to the-; draft. This deals with whint he did as Vice President.

[1 minute 28 second summary of Clinton's day and campaign plans]

Note that Jennings uses an embedded metapragmatic construction very similar to Gestoso's, in describing the Clinton response. So Jennings, too, takes advantage of the opportunity to use the strong metapragmatic verb has been lying to voice Bush, without having to take responsibility himself for the word choice. In all the direct quotes presented from Clinton and his campaign workers on October 30 , none of them actually 
use the verb to lie. Clinton and his Vice Presidential running mate Al Gore do say Bush has not "told the truth", and that what he said was 'untrue', but they stop short of direct accusations of lying. So both Gestoso and Jennings put this slightly more blunt accusation in Clinton's mouth, and thus strengthen their voicing of Bush. The phrase 'smoking gan', used by Jennings in [6] above, is a direct quote from Gore, and indexes (device \#4) a criminal context-as if Bush were guilty of a serious crime:

Bury, the ABC correspondent who normally covers the Clinton campaign, begins his report by reiterating Jennings's 'reversal' frame. Clinton has been 'attacked' (device \#2), and he is counter-attacking on the issue of character that Bussh has so often used against him. Bury atso includes a quote from Clinton that indexes the narrating event. Clinton says that Bush must answer 'your' (i.e., the press's) questions on this issue of character. And, by reporting the story as they are, $A B C$ is living up to this responsibility. As we will see below, however, they do not do it exactly as Clinton might have wanted.

[7] JENNINGS: ... Mr. Bush started this day by accusing Governor Clinton of what he called trample down economics. He ended it by having to answer those new questions about his role, in Iran Contra. Here's ABC's Britt Hume.

HUME: The wildness of yesterday's campaigning gave way today, to a more solemn and basic message from the President. He stopped calling his opponents Bozos, something even Mrs. Bush had said she disapproved of. Instead he framed his direct appeals for yotes in terms of his record.

BUSH: Ideas, action, character. I believe I havo demonstrated, I certainly have tried to demonstrate all three ... [36 second summary of Bush's campaign events of the day]

HUME: ... The President got a little boost today from Democratic Governor Donald Shaefer of Maryland, who came to St. Lowis to announce he's endorsing Mr. Bush. But there was also the perisistent issue of the Iran arms aales, fueled today by the release of that Weinberget note. The President insisted that it was all old stuff, that had been fully investigated.

BUSH: There is nothing contradictory in there of what Pve said. And I don't believe there's anything in there that's going to contradict the $\mathbf{4 0}$ million dollars that has been spent on these hearings.

HUME: The guestions raised by that Weinberger note may not be new but its public release is. It may not prove anything, the President has always said he missed part of that meeting. But it gives the whole issue new light. Hardly a help to him as he seeks reelection on the issues of character and trust. Britt Hume, ABC News, St. Louis.

In introducing Bush's response to the Weinberger note, Jennings reiterates the 'reversal' frame. Consistent with the voicing from above, Bush has to 'answer questions' about' this truthfulness (device \#2), and this turn- about puts him on the defensive with regard to the character issue. Britt Hume, the $\mathrm{ABC}$ correspondent who regularly reports on Bush, picks up the idea of a reversal but changes it slightly. Yesterday's Bush campaign (and in fact much of his months-lóng attack on Clinton's character) was 'wild', but today it's 'solemn'. These terms might index (device \#4) the shift from being on the attack to being defensive, but 'solemn' does not have quite the right connotations for this. And when Hume goes on to say that Bush 'framed his direct appeals for votes' (device \#2), we begin to see the difference between Jennings and Hume's ventriloquation more clearly. Hume seems to approve that Bush has given up his wild attacks. If 'even Mrs. Bush' has publicly indicated her disapproval of these tactics, Hume probably does too. But Hume portrays Bush's new persona more sympathetically-not. as defensive, but as earnestly making 'direct appeals'. In Hume's account, Bush gave up the wild attacks on his own, without reference to the Weinberger notes. The clip from Bush does mention the issue of character, which reminds the viewer that Bush has suffered a reversal on this issue. But overall the clip makes Bush seem relatively solemri, and even sympathetic.

After a brief discussion of other Bush campaign issues, Hume returns to the Weinberger notes. He has Bush 'insistitig' (device \#2) that be told the truth. Insist is less associated with criminals than deny-which is the verb that CNN, CBS, and even Jennings use for Bush in this context. Hume is again more sympathetic, voicing Bush as less likely immoral. Note also that: Hume describes the issue as 'fueled' by the release of the notes. This presents the controversy as if someone is deliberately making it worse, like an arsonist setting a fire (device \#4). According to this metaphor, Bush would be more the victim than the criminal. Following up Jennings's mention' of the special prosecutor who decided to release the note, Hume has Bush insist that it is 'all old stuff'- and if there were no new facts, then the motive for releasing the note must have been political.

In his last speaking turn, Hume himself suggests that the notes 'may not be new'. Here we begin to see the ventriloquation more clearly. Not only does Hume voice Bush as less morally suspect than both Gestoso and Jennings do, but he also appears himself sympathetic to Bush's position. This becomes even clearer as Hume proceeds to defend Bush, by introducing evidence (device \#5) that would nullify the accusation that Bush lied about the arms shipment. Bush and his campaign were apparently incapable of making the argument, but Hume suggests that Weinberger's notes may in fact not contradict Bush's statements (because Bush may have missed part of the meeting in question). But, Hume concludes, the truth may not matter because the issue has been given 
'new light'. That is, Bush may well lose the public relations game, and that's what seems to matter. Although he ends with this pessimistic conclusion for Bush, Hume also ends sympathetically: this is all thardly a Kelp' to Bush. This is not the sort of thing one would say (device \#4) when recounting the misfortune of a criminal or an enemy -unless one were being sarcastic: But Hume sounds and looks earnest here.

So $\mathrm{ABC}$ ends up with two different sorts of voicing and ventriloquation. Jennings voices Bush as a potentially deceptive politician, but he does not take this as seriously as CNN. It is instead all part of the political game, and turnabout is fair play. Hume recasts the reversal that Bush suffers; and portrays him more sympathetically - as one who realized his own mistakes and is working to change them, and even as one victimized by the political game that Jennings seems mildly amused by. Hume himself ends up defending Bush.

CBS' coverage of this incident differs dramatically from both CNN and $A B C$, both in structure and in voicing and ventriloquation. CBS gives the story much more space-ailmost 1300 words. The structure of the report is also different. Instead of the anchor reporting the issue, and. going directly to the campaign correspondents for responses, another correspondent reports the bulk of the story before going to the campaign responses. This initial correspondent is the CBS. news "law correspondent'- which tells us something important about the frame CBS places on the story. The newscast is organized as follows.

1. Anchor introduction/frame

2. Law correspondent report of the facts including clips from journalists and Bush's own past claims

3. Anchor return, to introduce campaign correspondents

4. Bush campaign correspondent

including clips from Bush and his campaign staff

5. Clinton campaign correspondent

including clips from Clinton and his campaign staff

6. Perot campaign correspondent including clip from Perot

7. Report of poll on whether public trusts Bush or Clinton more.

The analysis shows that the selection of the law correspondent is no accident. This newscast enacts a definite trope: George Bush is put on trial. The law correspondent Rita Braver acts like a prosecutor, and she calls 'expert witnesses' to make her case against Bush. The anchor himself (Dan Rather) enters as a sort of witness, and warns us about Bush's lies. The Bush campaign correspondent then provides an unconvincing rebuttal. Next Clinton and.Perot get to 'testify' against Bush. The segment ends with a vote from the "jury', a poll that shows the public distrusts Bush far more thian Clinton. Thus the "trial' ends, and Bush is 'convicted".

From the beginning, Rather presents this story as a legal matter. In. the introductory segment, which briefly summarizes the top stories of the day, Rather's first words are: 'A secret arims deal with Iran. A grand jury sees evidence contrary to what President Bush repeatedly has said'. So already we have 'grand jury' involvement, which indexes (device \#4) a legal frame. As Rather presents it here, it even sounds as if the grand jury might be indicting Bush himself. We do not learn until the third sentence of the law correspondent's report ( 120 words into the story) that the grand jury is indicting Weinberger and not Bush.

After the titles, Rather begins the newscast as follows:

Dan Rather reporting. There is new written eviderice tonight concerning what President Bush knew and when he knew about the secret deal; that sent some of America's best missiles to Iran's Ayatollah Khomeini. The grand jury evidence raises new questions about whether Mr. Bush is telling the truth. CBS News law. correspondent Rita Braver, has details on this dramatic turn of events.

Note first the emphasis on 'new' evidence. Rather uses this word twice, and other correspondents pick it up later. Andmat the end of this passage Rather labels with Weinberger notes a 'dramatic turn of events'. Later on, other CBS correspondents use the terms 'bombshell' and 'revelation' to describe the notes as well (device \#1). So CBS frames the story as very serious new questions about whether Bush has been telling the truth. Rather makes these questions even more serious by using terms that index (device \#4) the terrible mistake that was. made: it was a 'secret deal', the sort of arrangement criminals make; it sent our 'best missiles'; not just generic armaments; and it sent them to the hated 'Ayatollah Khomeini' (Americans particularly detested Khomeini for his role in kidnapping US hostages in 1979-1981; so much so that Nuke the Ayatollah' was a common slogan until his death). 'Rather further reinforces the seriousness of Bush's predicament by paraphrasing the legal question as 'what President Bush knew and when he knew'. Almost these same exact words were used in the investigation of Nixon during Watergate (device \#4), and Nixon was forced to resign because of the charges against him. All of this makes the questions about Bush seem extremely serious.

The frame CBS uses to investigate such questions is legal. Rita Braver, the law correspondent, presents the evidence against Bush.

BRAVER: An embarrassing revelation for George Bush. Evidence released for the first time today, contradicts his previous statements that he was out of the loop on the Reagan administration's deal, to ship arms to Iran in exchange for 
American hostages. New charges returned in the ongoing case against former defense secretary Caspar Weinberger detail Weinberger's handwritten notes, of a meeting George Bush attended, January 7 1986. Weinberger writes [page of text, with quote from notes] that President Reagan decided to approve a scheme to release hostages in return for the sale of $4000 \mathrm{TOW}$ imissiles to Iran by Israel: Weinberger opposed. Others, including Vice President Bush, favored the deal.

LEWIS: This is further, very strong evidence, that George Bush knew all about the trading of arms for hostages, which he has consistently denied.

BRAVER: For years, gver and over again, Mr. Bush claimed neither he nor President Reagan knew the details.

BUSH [12/3/86]: The President is absolutely convinced. (2 second pause) That he did not swap anms for hostages.

BRAVER: President Bush has changed his story geveral times, and in fact earlier this month, appeared to admit he knew something about the deal.

INTERVIEWER [10/13/92]c You knew about the arms for hostages.

BUSH [10/13/92]: Yes. And I've said so all along.

Braver here picks up Rather's use of the term 'deal' to refer to the arms sale, and also uses 'scheme'. Both these words often index criminal acts (device \#4). Like Gestoso, she uses the metapragmatic verb 'contradict' (device \#2) to emphasize the new evidence that Bush has been lying. Like Gestoso and Jennings, she also presents details of the notes, and thus reinforces their objectivity (device \#5): the notes are 'handwritten', they describe a meeting on a specific date, and they specifically mention 4000 missiles. Unlike Hume, she raises no question about Bush's attendance at the meeting in question.

But Braver goes beyond Gestoso and Jennings, when she proceeds to call a witness and present further evidence against Bush. Anthony Lewis is a New York Times journalist; who followed the Iran Contra scandal , closely. He indicts Bush bluntly, as one would expect a prosecution witness to do-by putting the verb deny in Bush's mouth (device \#2), and by claiming that Bush really 'knew all about' the deal. Then Braver illustrates Bush's 'claims'. with his own words (like deny, claim is a metapragmatic yerb often associated with legal defendants). She produces, as an exhibit, a tape of Bush denying that Reagan knew of the swap. Like a good prosecutor, she then produces more evidence-again an exhibit in Bush's own words - that he 'has changed his story' (along with 'admit', this is another type of predication associated with legal defendants; device \#2). The contradiction between the two Bush quotes is blunt, and leaves the clear impression that Bush must have been lying at some point.

Braver continues her case by calling on Lewis once more.

BRAVER: But in that same interview the President also denied; being at key meetings, including the one in the note released today, where Weinberger opposed the trade. New York Times columnist Anthony Lewis, who's been tracking the President's Iran-Contra connection, says it's ironic George Bush is trying to make Bill Clinton's truthfulness an issue.

LEWIS: It's the Bresident of the United States deliberately, knowingly, forcefully telling you an untruth, year after year, month after month. That's going to destroy our faith in our political system.

BRAVER: The independent counsel insists the release of the note was timed to meet the schedule for Caspar Weinberger's trial, not to embarrass the President in the final days of the campaign. Rita Braver, CBS News, Washington.

Here Braver mentions the ironic reversal of focus from Clinton's character to Bush's-but she does so only in passing, and does not make this central to her presentation of the story (unlike Jennings). In introducing Lewis, note that she also uses the phrase 'the President's Iran-Contra connection". The term 'connection' is yet another associated with criminal activity (device \#4), and thus she reinforces the voicing of Bush as a criminal defendant facing serious charges. Lewis continues along these lines, by claiming that Bush has been repeatedly lying. $\mathrm{He}$ also identifies the victim of the crime: our political system is losing credibility because of Bush's lies.

At the very end of her report, in one sentence, Braver mentions that the release of the evidence might have been politically motivated. After the strength of her case against Bush, this possibility is barely in play as she signs off. In the next utterance, however, Rather ignores this possibility completely and himself joins the case against Bush.

RATHER: The grand jury evidence appears to be at variance with what thenVice President Bush said in an interview on this broadcast in 1988. The President sent one of his spokesmen out today to say, there is nothing new in the Weinberger note. White House correspondent Susan Spencer is with the President, on the campaign trial in St. Louis. Susan?

Note again that Rather reinforces the legal frame by referring to the Weinberger notes as 'grand jury evidence" (device \#1). He goes on to cite more evidence (device $\# 5$ ) that Bush has been lying: four years ago on this very program (the CBS Evening News), with Dan Rather himself as the interviewer, Bush made claims that are contradicted by the new Weinberger evidence. Rather thus serves as a witness, providing corroborative evidence against Bush. But he is also in control of the broadcast, and in this role.be orchestrates Bush's 'trial'. So Rather's ventriloquation here seems to be: Bush lied to me too, and I'm here both to hold him responsible and to warn you about him. (We should also note that, during the on-air 1988 interview Rather refers to, Rather and Bush engaged in a serious struggle for control. Bush condescended to Rather, 
and Rather struggled to regain his stature throughout the interview. By indexing this event, Rather points to the reversal of roles that he is undoubtedly enjoying - with Bush the accused, and thus subordinate to Rather, who is more like the judge or the trusted court reporter.)

Next Rather goes to the three campaign correspondents. He starts with Susan Spencer, who covers Bush. In his introduction to her, note the quotation he uses (device \#3): Bush's spokesman says 'there is nothing new in the Weinberger note'. This assertion runs counter to Rather and Braver's repeated assertions that this evidence is 'new', and a 'revelation'. Thus Rather makes it clear once again that he and CBS are not on Bush's side. Spencer goes on as follows:

SPENCER: Dan the Bush campaign was both very angry and very defensive about this story. Saying that any claim that this somehow contradicts Mr. Bush's assertion that he was not in the loop on the arms sale is quote, pure political hogwash. Aides insist that the President has answered every question on this, that nothing has changed, and that everything in this memo was already known. So when asked about the newr memo, spokesman Marlin Fitzwater had this somewhat odd reaction.

FITZWATER: There isn't one. Yea.

SPENCER: The campaign may try to laugh it off, but Mr. Bush does not need any questions about his truthfulness when he's trying to convinoe voters that he, unlike Governor Clintou, is the man of honor and trust, a point he made today at a surprisingly small afternoon rally, in Missouri.

BUSH: What the President does reflects all around the world. It's- people judge our country to a large degree by that. They are interlocked and I don't believe you can have a person in the White House who's going to try to be on all sides of every issue, flip-flopping. The pattern of deceit is wrong for America.

SPENCER: Aides said none of this would lessen Mr. Bush's enthusiasm for the character issue. Added spokesman Fitzwater, I hate to accuse anyone of politics, but it does seem mighty suspicious that the Clinton people would try to stir this thing up. Dan.

So the Bush campaign was 'defensive' (device \#2) - like a defendant, and a guilty one at that. Spencer directly quotes (device \#3) two of their responses. First, they claim the new charges are 'pure political hogwash'. And then, in the face of Spencer's request for a response on the 'new' evidence; they say 'there isn't one [a response]; yea'. Spencer's metapragmatic comment on this utterance is that it was 'odd'. This is an understatement, given that the video shows Fitzwater doffing his hat and saluting the crowd as he says 'yea'. After the serious, detailed presentation of evidence that CBS has just put forth against Bush, these two responses seem silly and unconvincing. Spencer labels them with a metapragmatic verb phrase (device \#2): Bush is trying 'to laugh it off'. She makes clear the inappropriateness of this response, given that Bush's 'truthfulness' is at issue. And she notes that he is now drawing 'surprisingly small' crowds. We wiil see the importance of the public's response below, in the report of poll results. They play the role of jury, and in staying away from Bush's rally they are 'voting' against him.

Spencer ends with a quote (device \#3) from Bush talking about Clinton's supposed 'deceit", which comes across as ironic given the newscast's emphasis on Bush's probable deceit. And she reports that the Bush campaign claims Clinton is 'trying to stir this thing up' (device \#2). This characterization is again at odds with the whole CBS portrayal of the new evidence-- on their account it is not Clinton at all, but a 'grand jury' and they themselves who are examining the notes. And it is not muck being stirred up, but serious new evidence against Bush.

Rather goes next to the Clinton correspondent.

RATHER: Susan Spencer, thanks. Governor Clinton was; guick today to once again question the President's truthfulness. Richard Threlkeld is with the Clinton campaign in Pittsburgh. Dick.

THRELKELD: Dan all along the Clinton campaign has been trying to make an issue of George Bush's credibility. The revelations today about Iran-Contra played right into that theme. $\rightarrow \infty$

CLINTON: Today's disclosure, that President Bush, knew and approved of the arms for hostages deal with Iran, not only directly contradicts the President's claims. It diminishes the credibility of the Presidency. It raises the question first o- most importantly about, whether he's told the truth uh in this campaign and for the last- uh five years. And secondly, it raises the whole question of his suppost for the policy. But the far more important thing is whether, for five years he's been telling the American people something about his conduct of foreign policy as Vice President, which was simply not true.

GORE: We now have the gvidence, the smoking gun memorandum, the clear proof that what George Bush has said about his role in creating one of the worst, most embarrassing catastrophes in American foreign policy, is simply untrue. How can he now ask the American people to trust him.

THRELKELD: Despite this bombshell the Clinton campaign still thinks that this election will turn on the issue of the economy, and Dan that's the issue thatthat Bill Clinton will be stressing in a campaign marathon the next three days that will take him to more than a dezen states, winding up uh at dawn on election day in Denver Colorado. Dan.

Here, after Braver's case against Bush and Bush's unconvincing defense, Clinton and Gore get called in to summarize and reinforce the case against him. (They might be like prosecution witnesses. Or they might be commentators; speculating on the outcome while the jury deliberates.) Threlkeld continues the characterization of Weinberger's notes as substantial new evidence, labelling them with the term "bombshell" 
(device \#1). Without much interpretation he lets Clinton and Gore speak for themselves. They run through the case against Bush again, citing the new 'disclosure' that 'directly contradicts' Bush's statements. They cite the 'smoking gun' evidence and present Bush's statements as 'simply untrue'. They also emphasize the 'catastrophic' nature of the Iran policy. All of this echoes Rather and Braver's case.

Next Rather'goes to the Perot campaign correspondent, for his report on the Weinberger notes. The inclusion of this segment further reinforces the weight that CBS is giving this story, in contrast to CNN and ABCwhich did not give Perot a voice on this issue at all:

RATHER: Richard Threlkeld, with the Clinton-Gore campaign in Pittsburgh, thanks. As for how the Ross Perot campaign is reacting to today's developments let's go to correspondent Bill Lagattuta at Perot headquarters in Dallas. Good evening Bill.

LAGATTUTA: Good evening Dan, here at the Perot campaign they'ro privately delighted at the timing of this Irangate development. They say it makes their candidate look more credible; when he attacks the party of George Bush.

PEROT: This is the same party that gave us Watergate. This is the same party that gave us Iran-Contra. This is the same party that's up to its ears in Irangate now.

LAGATTUUTA: Revisiting his political birthplace last night ...

[1 minute, 54 second report on other issues in Perot's campaign]

Lagattuta casts Perot as 'attacking' (device \#2) Bush, which completes the line up against him (the grand jury, Weinberger's notes, the special prosecutor, Braver, Lewis, Rather, Clinton, Gore, and now Perot). Both Lagattuta and Perot also reinforce the similarity between Bush's current cover-up and the Watergate scandal, a similarity which Rather introduced at the beginning. Lagattuta uses the term 'Irangate', which borrows the -gate suffix from Watergate and thus indexes political scandal (device \#4). The quote from Perot explicitly assoeiates Bush and his party with Watergate: This further reinforces the voicing of Bush as a lying politician who faces serious consequences.

Within the 'courtroom' genre of the broadcast, these consequences for Bush follow immediately after Lagattuta's report. In the next segment Rather introduces a new poll-a 'full poll', he says, 'not a tracking poll'.

RATHER: ... It indicates that Governor Clinton may be hanging on to his lead over President Bush. The survey was completed before today's weapons for Iran new evidence. But the Clinton Gore ticket, in this survey appeared to be the choice of forty-five percent of likely voters. Bush Quayle ten points behind, and Perot Stockdate with fifteen percent. Correspondent Mark Phillips has more, about these numbers and what they may mean.
PHILLIPS: For a President campaigning on the trust issue, and who's now fighting off another Iran Contra bombshell, there are some worrying numbers in today's CBS News poli, about whether people believe what he says. The issue here is Iraqgate. Mr. Bush has said he didn't know Saddam Hussein was using US aid to build up his military before the Gulf war. But the polls show twice as many people don't believe him as do. That's fewer people than believe Bill Clinton's version of his Vietnam War draft history. Here the public is split between belief and disbelief ....

Although this poll does not specifically examine Bush's credibility with regard to the Iran arms shipment, its placement at this point in the broadcast make it seem much like a jury verdict. On the issue of Bush's credibility the public find him guilty of lying, by a ratio of two to one. We can only expect, Phillips implies, that the new 'bombshell' evidence against him will make the verdict even more lopsided.

This verdict completes the quasi-legal proceeding that CBS has staged against Bush. We heard a convincing case from Braver, including firsthand testimony from Rather himself, a feeble defense from Bush, and various opinions that corroborate the prosecution (Lewis, Clinton, Gore, Perot). Now the public has indicated its belief that Bush is lying. (The 'sentencing' has to wait for the actual election, as the voters are the ones empowered to depose Bush. And this, of course, they did). So CBS voices Bush as a criminal defendant, one who is most likely guilty. As for ventriloquation, their position is as the prosecution-tesponsible for making the case against Bush and warning the public.

\section{Conclasion}

As these analyses show, analysis of voicing and ventriloquation can uncover implicit messages that newscasters send about political candidates. Through systematic attention to the five devices described above, we have been able to develop and substantiate accounts of media bias in the three newscasts analyzed. Two important questions arise here. First, can we disciuss politics without giving off this sort of implicit message? If we want to continue discussing what politicians are like and what they say, we probably cannot avoid voicing and ventriloquation (Verschueren, 1985; Wilson, 1990). All quotation, to take one of the devices, requires the newscaster to put some words in the candidate's mouth. And all words, as Bakhtin tells us, come with some social position attached. As we have seen, newscasters will often differ in the social positions and evaluations they attach to political candidates. In discussing politics, 
then, we cannot help but voice and ventriloquate the candidates. Implicit messages are almost inevitable.

But they need not be insidious. Once we recognize how morally laden newscasters' comments can be, perhaps we can control the process. Ventriloquation need not convey implicit messages, if journalists can discuss the issues more explicitly. In fact, the inevitability of voicing and ventriloquation might provide opportunities. If journalists could be more explicit about their messages, and about the aspects of language use that communicate these messages, they could more successfully invite audiences to make up their own minds. This sort of open discussion might contribute to audiences' understanding of politics, and it might avoid the potentially insidious consequences of implicit messages.

Second, do the five devices described here exhaust the resources for voicing? The five devices for voicing are useful tools for analyzing implicit messages. However, these five tools cannot suffice. Other aspects of utterances contribute to voicing and ventriloquation. Furthermore, as mentioned above, the tools cannot be applied mechanically. The process of orchestrating an implicit message is 'poetic' (Jakobson, 1960; Silverstein, 1992). Speakers do not mechanically apply rules to obtain intended outcomes. Instead, they artfully constrict messages within particular interactional contexts. Any adequate analysis of actual interaction must give a contextualized account of the implicit messages. We claim that it is particularly prodictive to start by looking at the five devices for voicing presented here, but the analysis must go beyond this to show how speakers use the devices to orchestrate a coherent whole.

With this caution in mind, however, a more systematic application of Bakhtin's concepts does promise to illuminate media bias. Further study of voicing and ventriloquation could describe more precisely the five devices, and perhaps uncover others. This sort of research might help journalists, among others, recognize and take responsibility for their implicit messages.

\section{References}

Bakhtin, M: (1981 [1935]). Discourso in the novel (translated by C. Emerson and M. Holquist). In The Dialogic Imagination, M. Bakhtin, 259-422. Austin: University
of Texas.

-(1986 [1953]). The problem of speech genres (translated by V. McGeo). In Speech Genres and Other Late Essays, M. Bakhtin, 60-102, Austin: University of Texas.

Bell, A. (1991). The Language of News Media Cambridgo, MA: Blackwell.

Besnier, N. (1992). Reported speech and affect on Nukulaelae. Atoll. In Responsibtlty and Evidence in Oral Discourse, J. Hill and J. Irvine (eds.), 161-181. New York: Cambridge
University.

Clark, H. and Gerrig, R. (1990). Quotations as demonstrations. Language 66: 764-805.
Davis, H. and Walton, P. (1983). Language, Image, Media. New York: St. Martin's. Fairclough, N. (1995). Media Discourse. New York: Bdwand Arnold.

Goffinan, E (1959). The Presentation of Self in Everyday Life. New York: Doubleday.

(1974). Frame Analysis. New York Harper and Row.

Goossens, L. (1982). Say: focus on the message. In The Scene of Lingulstic Action and its Perspectivization by Speak, Talk, Say and Tell, R. Diryen, L. Goossens, Y. Putsey's and E. Vorlat (eds.), 85-131. Amsterdam: John Benjamins.

Irvine, J. (1992). Insult and responsibility. In Responstbility and Evidence in Oral Discourse, J. Hill and J. Irvine (eds.), 105-134. New York: Cambridge University.

Jakobson, R. (1960). Concluding statement: Linguistics and poetics. In Style tn Language, T: Sebeok (ed), 350-377. Cambridge: MTT.

-(1971 [1957]). Shifters, verbal categories, and the Russian verb. In Selected Writhgs, R. Jakobson, Vol. 2: 130-147. The Hague: Mouton.

Levinson, S. (1981). The sential inadequacies of speech act models of dialogue. In Possibilities and Linitations of Pragmatics, H. Parret, M. Sbist and J. Verschueren (eds.), 473-492. Amsterdam: John Benjamins.

Locher, M. and Wortham, S. (1994). The cast of the news. Pragmatics 4: 517-534.

Mayes, P. (1990). Quotation in spoken English. Studies in Langiage 14: 325-363.

Parmentier, R. (1993). The political function of reported speech. In Reflexive Language, J. Lucy (ed), 261-286. New York: Cambridge University.

Pynchon, T: (1959). Mortality and mercy in Vienna. Epoch 9: 195-213.

Schiffin, D. (1990). Between text and context. Text 10: 245-270.

Silverstein, M. (1976). Shifters, linguistic categories, and cultural description. In Meaning in Atthropology, K. Basso and H. Selby (eds) 1 - 1-55, Albuquerque: University of New Mexico.

- (1988). De-voice of authority. Paper read at 87th Annual Meeting of the American Anthropological Association, Phoenix, Arizona.

-(1992). The indeterminacy of contextualization: When is enough enough? In The Contextualization of Larguage, A. DiLuxio and P. Auer (eds.), 55-75. Amsterdam: John Benjamins.

-(1993). Metapragmatio discourse and tnetapragmatio function. In Reflextve Language, J. Lucy (ed.). New York: Cambridge University.

van Dijk, T. (1988). News as Discourse. Hillsdale, NJ: Lawrence Erlbaum Associates.

Verschueren, J. (1985). Intermattonal News Reporting. Amsterdam: John Benjamins.

Volosinov, V. (1986 [1929]). Marxism and the Philosophy of Language (tranglated by L. Matejka and L. Titunik). Cambridge, MA: Harvard University Press.

Waugh, L. (1995). Reported speech in journalistic discourse. Text 15, 129-173.

Wilson, J. (1990). Politically Speaking. Cambridge, MA: Basil Blackwell.

Wortham, S. (1994). Acting out Participant Examples in the Classroom. Amsterdam: John Benjamins.

Stanton Wortham teaches at Bates College. His research has focused on how the details of language nse create particular relational patterns in multiethmic secondary school classrooms. A comprehensive report of this research has just been published by John Benjamins, as Acting out participant examples in the classroom. His current work involves the systematic use of Bakhtintan concepts to understand evaluative speech in classrooms, newsrooms, and self-narratives.

Michael Locher is a doctoral candidate in the Department of Anthropology at the University of Chicago, where he works with Marshall Sahlins and Michael Silverstein. His doctoral research focuses on metapragmatic langugge use and ritual events among the Sundanese in Western Java 